\title{
Geochemical and hydrogeochemical characteristics and evolution of Kozakl1 geothermal fluids, Central Anatolia, Turkey
}

\author{
Mehmet Furkan Şener ${ }^{\mathrm{a}, *}$, Alper Baba ${ }^{\mathrm{b}}$ \\ ${ }^{a}$ Nigde Omer Halisdemir University, Faculty of Arts and Sciences, Department of Geography, 51240, Nigde, Turkey \\ ${ }^{\mathrm{b}}$ Izmir Institute of Technology, Geothermal Energy Research and Application Center, 35430, Izmir, Turkey
}

\section{A R T I C L E I N F O}

\section{Keywords:}

Kozaklı

Geothermal

Geochemistry

Stable isotope

Rare earth elements

Turkey

\begin{abstract}
A B S T R A C T
Kozaklı is one of the most important areas of Central Anatolia in terms of geothermal potential and it is characterized by thrust and normal faults. These faults, accommodating deep circulation of hydrothermal fluids of meteoric origin, are the primary controls of the geothermal systems in this region. Chemical and isotopic composition of the hot springs and geothermal fluids was monitored throughout 2017. The surface temperature of the fluid ranges from 24.9 to $96^{\circ} \mathrm{C}$. The cold spring waters are mostly of the $\mathrm{Ca}-\mathrm{Mg}-\mathrm{HCO}_{3}$ type in the study area. Major element chemistry of the water reveals that the deep geothermal fluids are mostly of the Na-Ca-Cl$\mathrm{SO}_{4}$ type while the shallow geothermal well waters are $\mathrm{Ca}-\mathrm{Na}-\mathrm{HCO}_{3}$ waters. Silica geothermometers suggest that the reservoir temperature ranges from 103 to $173^{\circ} \mathrm{C}$. Based on the $\delta^{18} \mathrm{O}-\delta \mathrm{D}$ relationship, water samples have a high-altitude meteoric origin. Stable isotopic data indicate that the geothermal fluids are formed by local recharge and deep circulation of meteoric waters. The Rare Earth Elements and Yttrium (REY) composition showed that $\mathrm{Eu}, \mathrm{Ce}$ and $\mathrm{Y}$ anomalies are related both to inheritance from geological host materials and the fractionation of these elements during water-rock interactions.
\end{abstract}

\section{Introduction}

The rapid increase in population and need for energy in developing industries is increasing the demand for energy. Today, most energy is supplied from fossil fuels and nuclear energy. Carbon dioxide $\left(\mathrm{CO}_{2}\right)$, which is the result of combustion of fossil fuels such as petroleum, coal and natural gas, causes a greenhouse effect in the atmosphere due to deforestation. Climate change, global warming and the need for clean energy sources mean that nearly all countries are turning to renewable sources such as solar, wind, biomass and geothermal energy. Geothermal energy applications have increased in many countries such as Turkey. Owing to its setting in the tectonically-active AlpineMediterranean Belt, Turkey has a significant geothermal potential (Baba and Ármannsson, 2006; Şimşek, 2009). This potential has been utilized in various local sectors to the extent of $1033 \mathrm{MWt}$ (Megawatts thermal), balneology $1005 \mathrm{MWt}$, heat pump applications $42.8 \mathrm{MWt}$, greenhouse applications $820 \mathrm{MWt}$, thermal hotel heating $420 \mathrm{MWt}$, food drying 1.5 MWt and electricity production (installed capacity: 1150 MWe (Megawatts electric) (Akkuş, 2017; Baba, 2018). Geothermal exploration and development are currently in progress to meet the increased demand for energy to be utilized in electricity production and heating.
The Kozaklı Geothermal Field is located in the northern part of the Nevşehir province in Central Anatolia (Fig. 1). Central Anatolia has important geothermal fields, where geothermal reservoir temperatures reach $297^{\circ} \mathrm{C}$. Currently, this geothermal energy potential is not used for electricity production but power generation facilities are under construction in Central Anatolia and geothermal fluids are being used for residential heating, greenhouses and thermal resorts. In the past five decades, many studies have been carried out to understand the geological, volcanological and tectonic properties of the region (Dirik and Göncüoğlu, 1996; Erişen and Özgür, 1999; Möller et al., 2004; Ok, 2007; Özgür et al., 1997; Pasvanoğlu et al., 2012; Şener, 2019; Şengör and Canitez, 2013; Temiz et al., 2009; Toprak and Göncüoğlu, 1993).

Worldwide, there is a need to understand water-rock interaction and other various geochemical processes by means of water chemistry, stable isotopes and rare earth element chemistry (Goldstein and Jacobsen, 1988; Elderfield et al., 1990; Smedley, 1991; Fee et al., 1992; Byrne and Lee, 1993; Johannesson et al., 1997; Zhang and Liu, 2004; Lawrence and Kamber, 2006). However, studies related particularly to the REY geochemistry of geothermal systems and fluids are limited in many geothermal systems (Möller et al., 2004; Şener et al., 2017). The series of Rare Earth Elements and Yttrium (REY) is a worthwhile tool in tracing the origin of geothermal fluids, which is fundamental to

\footnotetext{
* Corresponding author at: Nigde Omer Halisdemir University, Faculty of Arts and Sciences, Department of Geography, 51240, Nigde, Turkey.

E-mail address: mfsener@ohu.edu.tr (M.F. Şener).
} 

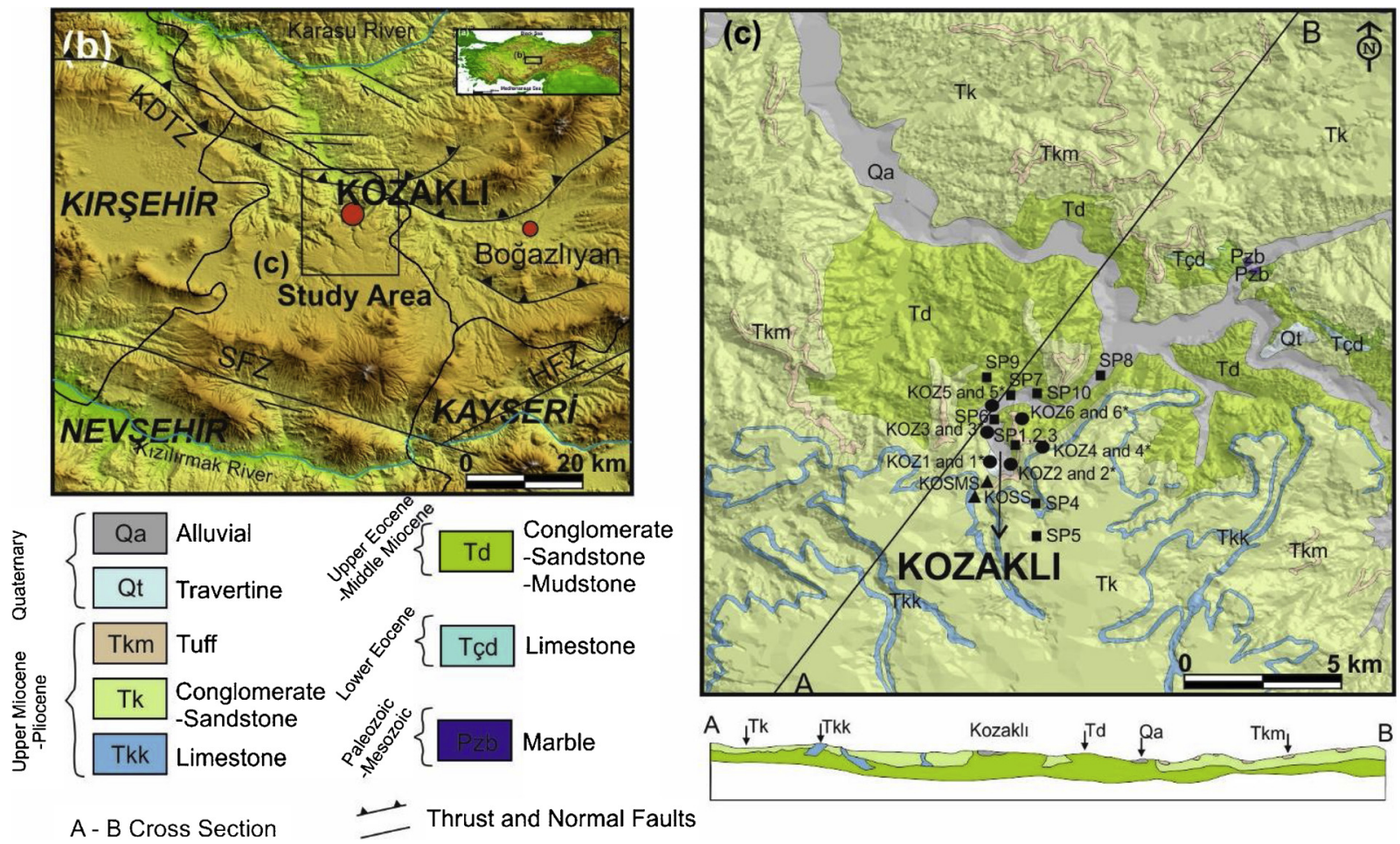

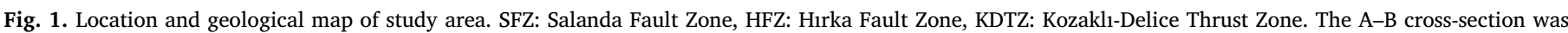
adapted from a 1/100,000 scale Geological Map of Turkey.

understanding a fluids-rock system. Therefore, geochemical and hydrochemical studies of geothermal fluid are necessary to gain a better understanding of the behavior of the fluids.

The purpose of this paper is to examine the source(s) and mechanism of the Kozaklı geothermal fluids using stable isotopes, hydrogeochemistry and rare earth elements to evaluate the potential of the field by means of a hydrogeochemical characterization, and hence to contribute to the efficient usage of the field. In this context, hydrogeochemical analysis was conducted on water samples collected from the wells and hot springs in the study area. The results were assessed in terms of the hydrogeochemical facies of the waters, possible subsurface processes comprising water-rock interactions and subsurface residence time, and geothermometer applications (reservoir temperature estimation) and scaling potential.

\section{Geological tectonic and hydrogeological settings}

\subsection{Geological setting}

The study area is located within the Paleozoic-Mesozoic Central Anatolian Crystalline Complex (Göncüoğlu et al., 1991). This Complex is a community which consists of metamorphic rocks and various felsic intrusive rocks (Göncüoglu et al., 1991). Volcanic rocks representing the Tertiary-Quaternary cover units and Miocene-Quaternary magmatism products lie unconformably on the Central Anatolian Crystalline Complex. Tamadağ and Bozçaldağ metamorphic rocks belonging to the Kırşehir massif are located in the basement of the study area. These metamorphic rocks consist of gneiss, schist and marble. The Paleozoic Tamadağ metamorphics contain phyllite, sericite-chlorite schist, calcschist and marble in alternation (Atabey, 1989; Seymen, 1981). This unit was cut by the Central Anatolian Granitoid consisting of granite, granodiorite and monzonite (Göncüoglu et al., 1991). The intrusion is of an Upper Cretaceous age. Eocene lacustrine deposits unconformably cover the Central Anatolian Crystalline Complex. These units in turn are unconformably overlain by Oligocene units consisting of red crossbedded sandstone, siltstone and mudstone. The Upper Miocene-
Pliocene Central Anatolian Volcanics consist of volcanic breccia, agglomerate, ignimbrite and tuffs that overlie in conformity with these Oligocene units (Fig. 1). Finally, a Quaternary alluvium layer consisting of gravels, silts and clays about $1-5 \mathrm{~m}$ in thickness covers all these units (Fig. 1). Quaternary travertine precipitations, which overlie the Upper Miocene-Pliocene unit, are also observed in various parts of the study area. These travertines are formed from geothermally-heated supersaturated meteoric waters, with an enhanced $\mathrm{CO}_{2}$ concentration. On emergence, the waters degas $\mathrm{CO}_{2}$ due to the lower atmospheric $\mathrm{CO}_{2}$ concentration, resulting in increased $\mathrm{pH}$. Because carbonate solubility decreases with increased $\mathrm{pH}$, precipitation is induced. The Kozakl travertines precipitate directly onto rock and other inert materials, such as in Pamukkale (Turkey) or Mammoth Hot Springs (USA). These Quaternary travertine precipitates unconformably overlie the Upper Miocene-Pliocene units. The apparent thickness of this Quaternary travertine in the region is between 50 and $60 \mathrm{~m}$ and the actual thickness is around $15-20 \mathrm{~m}$.

\subsection{Tectonic setting}

The study area is bordered by the North Anatolian Fault Zone, the Eastern Anatolian Fault Zone and the Tuzgölü Fault Zone to the north, east and west, respectively and was affected by a confined regime until Late Pliocene due to the convergence of the Arabian and Eurasian plates. Under the confined regime, the Middle Kizıllrmak and Sivas basins were enclosed and thrust faults developed near the study area. Successive anticlines and synclines with NE-SW axes that developed in the Upper Pliocene volcanic and sedimentary units indicate that the compressional regime continued to Late Pliocene. Due to these tectonic effects, the Kizılırmak Fault Zone caused the Kizılırmak basin to open and a typical horst graben structure developed in the region. The faults forming the graben are oblique and form the Middle Kizilırmak Fault Zone (Dirik and Göncüoğlu, 1996). One of the most important faults in the study area is the Salanda Fault Zone (Koçyiğit and Doğan, 2016; Öztürk et al., 2018; Şener et al., 2018), which is $20 \mathrm{~km}$ wide and $140 \mathrm{~km}$ long and extends parallel to the Salt Lake Fault Zone (Fig. 1b). 
The Salanda fault is a right-lateral strike-slip fault with a significant amount of normal components and comes into contact with the Upper Miocene-Pliocene terrestrial sediments and the Paleozoic Bozçaldağ metamorphics in the south of the Hacıbektaş district (Koçyiğit, 1984). Two other important faults are the broken line $20 \mathrm{~km}$ long located between Civelek and Gümüşkent, south of Hırkadağ and the Hırka Fault Zone, which covers the Yemliha and Felahiye faults and forms a part of the Central Anatolian Fault (Fig. 1b).

\subsection{Hydrogeological setting}

The geothermal area of the Kozaklı district in the Nevşehir province is the hottest geothermal area in Central Anatolia. At Kozakl1, thermal waters are manifested along a valley with a length of $1.5 \mathrm{~km}$ and a width of $200 \mathrm{~m}$ (Pasvanoğlu and Chandrasekharam, 2011). The measured temperature of the Kozaklı waters ranges from 43 to $51{ }^{\circ} \mathrm{C}$ in springs to $80-96^{\circ} \mathrm{C}$ in wells. The waters issue into a wide swampy area as a small group of springs through buried faults. Electrical conductivity values for the thermal springs and well waters are 1650-3595 $\mu \mathrm{S} / \mathrm{cm}$ and a pH values are 6.72-7.36. The Kozaklı cold water has an electrical conductivity of $450 \mu \mathrm{S} / \mathrm{cm}$ and $\mathrm{pH}$ of 7.56. Approximately 30 geothermal exploration and production wells have been drilled in the Kozaklı geothermal field since 1965, and the depth of the wells ranges from 60 to $1488 \mathrm{~m}$. During summer, water is pumped from the wells. The waters have a temperature range of $45-96^{\circ} \mathrm{C}$ and their discharge rate is $2-40 \mathrm{l} / \mathrm{s}$. Waters hotter than $90{ }^{\circ} \mathrm{C}$ issuing from a well $150 \mathrm{~m}$ in depth may indicate the presence of a still-cooling magma chamber beneath the Kozaklı area (Pasvanoğlu and Chandrasekharam, 2011).

Results indicate that the Paleozoic unit contains water sources due to fractures and cracks that developed. The Paleozoic units are the reservoir of the geothermal system. An Oligo-Miocene unit composed of gypsiferous, red-colored sandy marls, clay, marly limestones and conglomerates constitutes an impermeable zone in the region. OligoMiocene rocks form the cap rocks of the geothermal system. The tuffmarl and limestone-marl contact points have low-flow cold water sources. The Quaternary travertine and alluvium are generally aquiferous. Cold groundwater sources circulate in shallow areas, while hot fluids circulate in permeable units in deep zones (Fig. 1c). NW-SE and NE-SW striking normal faults and secondary fault systems control not only the manifestation of hot waters but also the Pliocene units exposed within the valleys.

\section{Materials and methods}

A total of 12 water samples from geothermal wells were collected for major ion chemistry, REY (Rare Earth Elements and Yttrium) and stable isotope ( $\delta^{18} \mathrm{O}$ and $\delta^{2} \mathrm{H}$ ) analysis during April 2017 and December 2017 (six samples each). Samples collected in April are denoted (*). These 12 samples were compared and interpreted in conjunction with 10 samples from Pasvanoğlu and Chandrasekharam (2011) and 2 samples from Afsin and Allen (2012). Unstable hydro-chemical parameters including water temperature $\left({ }^{\circ} \mathrm{C}\right), \mathrm{pH}$, electrical conductivity (EC) and dissolved oxygen (DO) were measured in situ using a portable $\mathrm{pH}$ meter, electric conductivity meter and a dissolved oxygen meter, calibrated before use. While sampling, all water samples were filtered through $0.45 \mu \mathrm{m}$ membranes on site. Samples were stored in new $350 \mathrm{ml}$ polyethylene bottles that were rinsed with deionized water twice before sampling. For the $\mathrm{SiO}_{2}$ analysis, the geothermal fluid samples were diluted ten-fold using deionized water to prevent $\mathrm{SiO}_{2}$ from polymerizing.

The chemical analysis of the major anions and cations was conducted in the Konya State Hydraulic Work's water chemistry laboratory. $\mathrm{Na}^{+}, \mathrm{K}^{+}, \mathrm{Ca}^{2+}, \mathrm{Mg}^{2+}, \mathrm{Li}^{+}, \mathrm{Al}^{3+}$ and $\mathrm{SiO}_{2}$ were determined with an atomic absorption spectrophotometer. $\mathrm{Cl}^{-}$and $\mathrm{HCO}_{3}{ }^{-}$(total alkalinity) were determined volumetrically and $\mathrm{SO}_{4}{ }^{2-}$ by the gravimetric method (Table 1). The anion-cation balance check is based on the percentage difference between total positive charge and total negative charge. $\delta^{18} \mathrm{O}$ and $\delta^{2} \mathrm{H}$ isotope analysis was carried out at the International Karst Water Resources Application and Research Center of Hacettepe University, Turkey and the results are shown in Table 3. Samples were analyzed using an isoprime Dual Inlet Isotope Ratio Mass Spectrometer (DI-IRMS) coupled to a multiprep bench for online analysis. $\delta^{2} \mathrm{H}$ was analyzed for after online equilibration at $40^{\circ} \mathrm{C}$ with a platinum catalyst (Hokko beads). $\delta^{18} \mathrm{O}$ were analyzed as above, but after equilibration with carbon dioxide. The $\delta^{18} \mathrm{O}$ and $\delta^{2} \mathrm{H}$ conformed to the international water standards of IAEA and USGS and were determined with a precision below $\pm 2 \%$ for $\delta \mathrm{D}$ and $\pm 0.1 \%$ for $\delta^{18} \mathrm{O}$. In addition, the Deuterium (d) excess value was calculated with the formula $\delta=\delta^{2} \mathrm{H}-\left(8 \times \delta^{18} \mathrm{O}\right)$ using the $\delta^{18} \mathrm{O}$ and $\delta^{2} \mathrm{H}$ isotope results. Deuterium excess values are sensitive to evaporation processes, including whether the summer or winter precipitation dominates the recharge (Jouzel and Merlivat, 1984). High d-excess values (higher than 10) generally indicate that more evaporated moisture has been added to the atmosphere (Gat and Matsui, 1991), and low values (lower than 10) are associated with samples fractionated by evaporation. Therefore, d-excess results can assist when interpreting the conditions of dry and rainy periods.

All water samples were analyzed for trace elements with a Thermo $\mathrm{X}$-series 1 quadrupole inductively coupled plasma mass spectrometer (ICP-MS) in the Acme Mineral Laboratories (Table 4). REY concentrations in natural waters are in the range of nmol/ $\mathrm{kg}$ to below $\mathrm{pmol} / \mathrm{kg}$. Therefore, REY have to be preconcentrated prior to analysis (Bau and Dulski, 1996; Möller et al., 1998; Shabani et al., 1992). In our study, preconditioning of the cartridges comprised: cleaning with $10 \mathrm{ml} 6 \mathrm{M}$ sub-boiled $\mathrm{HCl}$, washing with $7 \mathrm{ml}$ ultra-pure water, freeing from water, and loading with a liquid ion exchanger consisting of a mixture of ethylhexyl phosphates. In the laboratory, the REY loaded cartridges from the field were washed with $50 \mathrm{ml} 0.01 \mathrm{M}$ sub-boiled $\mathrm{HCl}$. Thereafter, the REY were eluted by $40 \mathrm{ml} 6 \mathrm{M}$ sub-boiled $\mathrm{HCl}$ at a rate of $3 \mathrm{ml} / \mathrm{min}$. High REY concentrations were determined with a precision within $\pm 5 \%$, whereas the lowest ones may vary by a factor of two due to uncertainties related to interference and limits of detection. All reported data were three times above the limits of detection. Sample preparation and the analytical procedures used were similar to those of Eggins et al. (1997).

\section{Results and discussion}

\subsection{Water chemistry}

The physical and hydrogeochemical data for fluids from the wells are presented in Table 1 . The water sources show slightly acidic $\mathrm{pH}$ values. The most abundant major ions are in the following order of abundance: $\mathrm{Na}^{+} \mathrm{K}^{+}>\mathrm{Ca}^{2+}>\mathrm{Mg}^{2+}, \mathrm{Cl}^{-}>\mathrm{SO}_{4}{ }^{2-}>\mathrm{HCO}_{3}{ }^{-}$. As observed, the geothermal fluids are mostly of the Na-Ca-Cl-SO ${ }_{4}$ type and the dominant ions are $\mathrm{Na}^{+}$and $\mathrm{SO}_{4}{ }^{2-}$; while the shallow well waters (KOZ4, KOZ6, KOZ4* and KOZ6*) and cold spring waters (SP4 and KOSS $* *)$ are of the $\mathrm{Ca}-\mathrm{Na}-\mathrm{HCO}_{3}$ type and the dominant ions are $\mathrm{Ca}^{2+}$ and $\mathrm{HCO}_{3}{ }^{-}$, as shown in the Piper (1944) diagram (Fig. 2).

The bicarbonate character of the waters seems to be compatible with the dissolution of reservoir rocks, which are dominated by Mesozoic limestones; whereas the dominancy of $\mathrm{Na}^{+}$cations in the geothermal fluid can be attributed to ion exchange (of the waters) with the overlying sediments, including the impermeable clayey levels. In general, sulfate-rich waters originate either i) in rocks such as evaporates, or ii) in the deep and long-duration circulation of the waters. All our deep geothermal fluid water samples show similar ion sequences in the semi-logarithmic Schoeller diagram (Fig. 3). This indicates that the waters are fed from the same or a similar source. However, in the semilogarithmic Schoeller diagram, the concentrations of $\mathrm{HCO}_{3}$ and $\mathrm{SO}_{4}$ in the samples are different. This can be explained by the fact that these samples were from different depths. The distinctions between the types 
Table 1

Measured parameters, major ion chemistry and $\mathrm{SiO}_{2}$ of water samples from Kozaklı geothermal region.

\begin{tabular}{|c|c|c|c|c|c|c|c|c|c|c|c|c|c|}
\hline Sample ID & $\mathrm{pH}$ & $\mathrm{T}\left({ }^{\circ} \mathrm{C}\right)$ & $\begin{array}{l}\mathrm{K}^{+} \\
(\mathrm{mg} / \mathrm{l})\end{array}$ & $\begin{array}{l}\mathrm{Na}^{+} \\
(\mathrm{mg} / \mathrm{l})\end{array}$ & $\begin{array}{l}\mathrm{Ca}^{2+} \\
(\mathrm{mg} / \mathrm{l})\end{array}$ & $\begin{array}{l}\mathrm{Mg}^{2+} \\
(\mathrm{mg} / \mathrm{l})\end{array}$ & $\begin{array}{l}\mathrm{HCO}_{3}{ }^{-} \\
(\mathrm{mg} / \mathrm{l})\end{array}$ & $\begin{array}{l}\mathrm{SO}_{4}{ }^{2-} \\
(\mathrm{mg} / \mathrm{l})\end{array}$ & $\begin{array}{l}\mathrm{Cl}^{-} \\
(\mathrm{mg} / \mathrm{l})\end{array}$ & $\begin{array}{l}\mathrm{SiO}_{2} \\
(\mathrm{mg} / \mathrm{l})\end{array}$ & $\begin{array}{l}\text { Sample } \\
\text { Type }\end{array}$ & $\begin{array}{l}\text { Charge } \\
\text { Balance }\end{array}$ & Water Type \\
\hline KOZ1 & 6.91 & 79.6 & 29.91 & 463.97 & 247.34 & 27.66 & 272.82 & 725.41 & 1069.81 & 128.32 & Well & -16.95 & $\mathrm{Na}-\mathrm{Ca}-\mathrm{Cl}-\mathrm{SO}_{4}$ \\
\hline KOZ2 & 6.54 & 66.1 & 24.41 & 534.18 & 163.46 & 26.76 & 322.33 & 583.66 & 419.85 & 82.48 & Well & 7.56 & $\mathrm{Na}-\mathrm{Ca}-\mathrm{SO}_{4}-\mathrm{Cl}$ \\
\hline KOZ3 & 6.82 & 58.7 & 26.58 & 438.73 & 212.85 & 25.25 & 342.59 & 521.53 & 392.63 & 78.89 & Well & 7.98 & $\mathrm{Na}-\mathrm{Ca}-\mathrm{Cl}-\mathrm{SO}_{4}$ \\
\hline KOZ4 & 7.12 & 24.9 & 12.01 & 216.79 & 575.78 & 22.33 & 867.27 & 312.39 & 88.26 & 74.73 & Well & -6.44 & $\mathrm{Ca}-\mathrm{Na}-\mathrm{HCO}_{3}-\mathrm{SO}_{4}$ \\
\hline KOZ5 & 6.37 & 64.4 & 28.28 & 374.18 & 151.57 & 26.71 & 331.57 & 574.43 & 337.45 & 84.63 & Well & -0.46 & $\mathrm{Na}-\mathrm{Ca}-\mathrm{SO}_{4}-\mathrm{Cl}$ \\
\hline KOZ6 & 7.25 & 29.2 & 18.62 & 258.92 & 681.45 & 26.35 & 735.54 & 313.67 & 83.36 & 87.41 & Well & 6.19 & $\mathrm{Ca}-\mathrm{Na}-\mathrm{HCO}_{3}$ \\
\hline KOZ1* & 6.93 & 77.9 & 29.79 & 366.14 & 233.57 & 21.18 & 270.65 & 721.55 & 1013.81 & 181.46 & Well & -23.30 & $\mathrm{Na}-\mathrm{Ca}-\mathrm{Cl}-\mathrm{SO}_{4}$ \\
\hline KOZ2* & 6.33 & 62.1 & 27.67 & 480.83 & 159.39 & 24.54 & 342.59 & 499.46 & 386.46 & 78.27 & Well & 7.78 & $\mathrm{Na}-\mathrm{Ca}-\mathrm{Cl}-\mathrm{SO}_{4}$ \\
\hline KOZ3* & 6.46 & 56.8 & 28.76 & 490.93 & 228.87 & 25.57 & 348.18 & 521.41 & 342.57 & 70.98 & Well & 1.03 & $\mathrm{Na}-\mathrm{Ca}-\mathrm{SO}_{4}-\mathrm{Cl}$ \\
\hline KOZ4* & 7.11 & 30.9 & 15.07 & 239.64 & 574.67 & 25.65 & 875.13 & 311.23 & 94.64 & 80.56 & Well & -6.92 & $\mathrm{Ca}-\mathrm{Na}-\mathrm{HCO}_{3}$ \\
\hline KOZ5* & 6.49 & 64 & 24.59 & 436.63 & 218.19 & 25.91 & 338.94 & 549.48 & 347.14 & 79.44 & Well & 3.50 & $\mathrm{Na}-\mathrm{Ca}-\mathrm{SO} 4-\mathrm{Cl}$ \\
\hline KOZ6* & 7.26 & 28.5 & 12.08 & 220.29 & 679.43 & 24.45 & 703.16 & 336.19 & 24.63 & 81.79 & Well & 3.59 & $\mathrm{Ca}-\mathrm{Na}-\mathrm{HCO}_{3}$ \\
\hline SP1 & 6.89 & 85 & 22.9 & 436.79 & 237.43 & 26.76 & 327.8 & 538.66 & 696.18 & 87.23 & Well & -4.00 & $\mathrm{Na}-\mathrm{Ca}-\mathrm{Cl}-\mathrm{SO}_{4}$ \\
\hline SP2 & 7.36 & 51 & 21.14 & 443.81 & 236.64 & 30.67 & 222.33 & 652.14 & 699.58 & 72.84 & Well & -4.19 & $\mathrm{Na}-\mathrm{Ca}-\mathrm{Cl}-\mathrm{SO}_{4}$ \\
\hline SP3 & 7.11 & 93 & 16.85 & 383.73 & 221.58 & 25.52 & 324.95 & 512.35 & 609.1 & 87.98 & Well & -4.84 & $\mathrm{Na}-\mathrm{Ca}-\mathrm{Cl}-\mathrm{SO}_{4}$ \\
\hline SP4 & 7.56 & 15 & 2.01 & 16.97 & 57.87 & 12.3 & 176.72 & 12.39 & 8.62 & 34.37 & Cold spring & 16.11 & $\mathrm{Ca}-\mathrm{Mg}-\mathrm{HCO}_{3}$ \\
\hline SP5 & 7.27 & 96 & 22.82 & 447.1 & 241.51 & 27.6 & 313.55 & 547 & 740.54 & 81.36 & Well & -4.57 & $\mathrm{Na}-\mathrm{Ca}-\mathrm{Cl}-\mathrm{SO}_{4}$ \\
\hline SP6 & 6.78 & 93 & 21.82 & 408.29 & 218.54 & 25.36 & 353.45 & 499.76 & 635.6 & 78.14 & Well & -4.59 & $\mathrm{Na}-\mathrm{Ca}-\mathrm{Cl}-\mathrm{SO}_{4}$ \\
\hline SP7 & 7.12 & 92 & 19.97 & 466.41 & 230.75 & 28.1 & 370.56 & 512.05 & 731.18 & 80.64 & Well & -4.10 & $\mathrm{Na}-\mathrm{Ca}-\mathrm{Cl}-\mathrm{SO}_{4}$ \\
\hline SP8 & 7.23 & 92 & 17.76 & 380.38 & 219.93 & 25.4 & 324.95 & 499.64 & 586.64 & 87.72 & Well & -3.82 & $\mathrm{Na}-\mathrm{Ca}-\mathrm{Cl}-\mathrm{SO}_{4}$ \\
\hline SP9 & 7.23 & 90 & 18.76 & 390.39 & 251.78 & 27.55 & 384.81 & 512.14 & 624.75 & 50.89 & Well & -3.71 & $\mathrm{Na}-\mathrm{Ca}-\mathrm{Cl}-\mathrm{SO}_{4}$ \\
\hline SP10 & 6.72 & 90 & 20.57 & 463.55 & 247.76 & 25.65 & 775.6 & 411.2 & 494.4 & 50.89 & Well & -0.28 & $\mathrm{Na}-\mathrm{Ca}-\mathrm{Cl}-\mathrm{SO}_{4}$ \\
\hline KOSMS** & 6.22 & 81.7 & 21.68 & 471.82 & 171.06 & 21.08 & 364.83 & 426.18 & 545.08 & 77.13 & Well & 1.53 & $\mathrm{Na}-\mathrm{Ca}-\mathrm{Cl}-\mathrm{SO}_{4}$ \\
\hline $\mathrm{KOSS}^{* *}$ & 7.25 & 12.8 & 1.31 & 7.07 & 63.99 & 10.14 & 163.44 & 7.78 & 3.99 & 36.93 & Cold spring & 19.48 & $\mathrm{Ca}-\mathrm{Mg}-\mathrm{HCO}_{3}$ \\
\hline Minimum & 6.22 & 24.90 & 12.01 & 216.79 & 151.57 & 21.08 & 222.33 & 311.23 & 24.63 & 50.89 & & & \\
\hline Maximum & 7.36 & 96.00 & 29.91 & 534.18 & 681.45 & 30.67 & 875.13 & 725.41 & 1069.81 & 181.46 & & & \\
\hline Average & 6.89 & 68.49 & 21.91 & 400.61 & 291.07 & 25.73 & 432.44 & 503.71 & 498.35 & 84.72 & & & \\
\hline Standard Deviation & 0.34 & 23.09 & 5.20 & 88.66 & 162.82 & 2.15 & 200.36 & 114.52 & 275.72 & 25.47 & & & \\
\hline
\end{tabular}

KOZ1; $2 ; 3 ; 4 ; 5 ; 6$ are April 2016 and KOZ1*; 2*; 3*; 4*; 5*; 6* are December 2016.

SP samples from Pasvanoğlu and Chandrasekharam (2011).

KOSS and KOSMS from Afsin and Allen (2012). Minimum, maximum, average and standard deviation calculated for geothermal fluid.

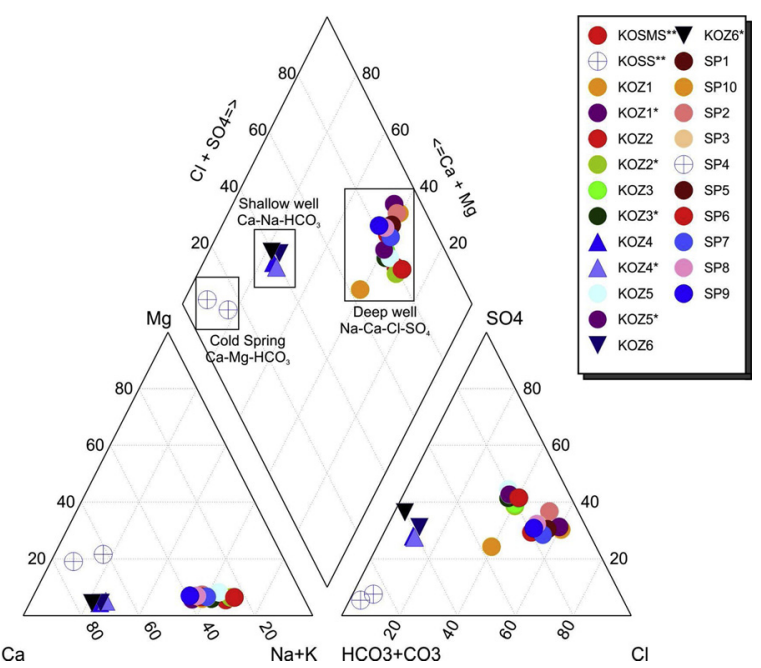

Fig. 2. Distribution of springs and geothermal fluids at Kozaklı in a Piper diagram.

of cold and geothermal fluid is clearly shown in the semi-logarithmic Schoeller diagram.

\subsection{Chemical geothermometry applications}

Chemical geothermometers, which are based on temperature-dependent water-rock equilibria, are used to estimate the reservoir temperature of geothermal systems and to give the last temperature of water-rock equilibrium attained in the reservoir. Chemical geothermometers also indicate that temperatures higher than those measured in a drill hole or a spring may be found. This is explained by the mixing of deep water with cold groundwater during its rise toward the surface.
The reservoir temperatures in the Kozaklı fields were calculated using a silica (quartz and chalcedony) geothermometer (Fournier, 1977). All geothermometry results are given in Table 2. Results for the quartz geothermometer gave reservoir temperatures ranging from 103 to $173^{\circ} \mathrm{C}$; while those from the chalcedony geothermometer were from 73 to $151{ }^{\circ} \mathrm{C}$. At temperatures of less than $180^{\circ} \mathrm{C}$, silica solubility is commonly controlled by chalcedony rather than quartz, as suggested by (Fournier, 1991). $\mathrm{SiO}_{2}$ concentrations of the studied geothermal fluids indicate that these waters may undergo silica precipitation during ascent to the surface. Accordingly, temperatures estimated by the chalcedony geothermometer may correspond closely to reservoir temperatures. Therefore, chalcedony geothermometers appear to reflect reservoir temperatures more accurately than quartz geothermometers (Mutlu, 1998).

Furthermore, some graphical methods have been developed based on the chemical equilibrium of major cations to determine the applicability of chemical geothermometers and to prevent errors that may occur in applying them to mixed cold and thermal fluids. The Na-K$\mathrm{Mg}^{1 / 2}$ ternary diagram was proposed by (Giggenbach, 1988) as a method to clearly distinction between thermal fluids that are suitable for the estimation of reservoir temperature by solute geothermometers (Fig. 4). All the thermal fluids in Kozaklı geothermal fields fall into the immature category, as seen in Fig. 4. Additionally, Şener et al. (2017) carried out a study of alteration zones in the Cappadocia region. These alteration zones consist of minerals such as jarosite, alunite, smectite and illite. Alteration minerals from rock samples, collected from the same location as the water samples display a similar pattern and chemical properties. This shows that thermal fluids reach the surface along a fault line and have caused the alteration of rocks by means of water-rock interaction. 


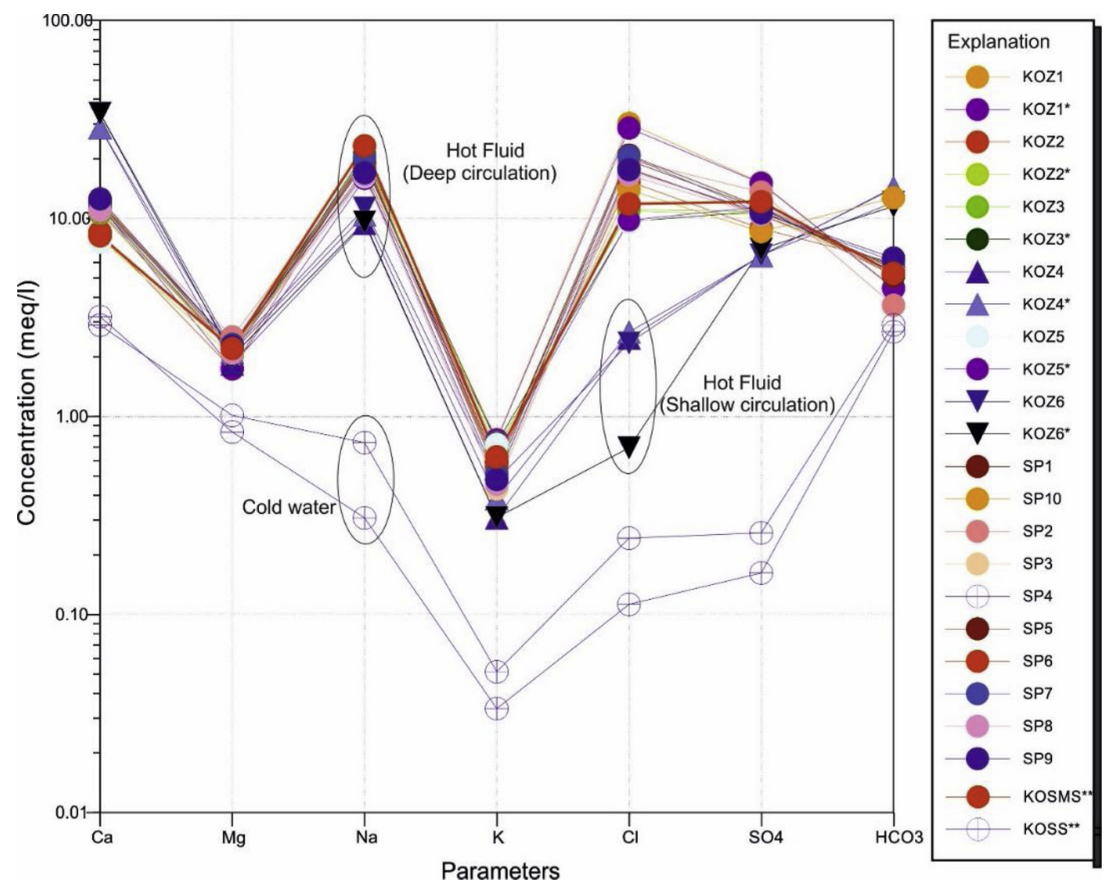

Fig. 3. Distribution of thermal waters from Kozaklı as semi-logarithmic Schoeller diagram.

Table 2

Estimated reservoir temperatures of the Kozakl1 thermal regions based on various chemical geothermometers.

\begin{tabular}{|c|c|c|c|c|}
\hline Sample No & $\begin{array}{l}\mathrm{SiO}_{2} \\
(\mathrm{Cristobalite} \alpha) \\
\left({ }^{\circ} \mathrm{C}\right)\end{array}$ & $\begin{array}{l}\mathrm{SiO}_{2} \\
(\mathrm{Cristobalite} \beta) \\
\left({ }^{\circ} \mathrm{C}\right)\end{array}$ & $\begin{array}{l}\mathrm{SiO}_{2} \\
\text { (Chalcedony) } \\
\left({ }^{\circ} \mathrm{C}\right)\end{array}$ & $\begin{array}{l}\mathrm{SiO}_{2} \\
\text { (Quartz) } \\
\left({ }^{\circ} \mathrm{C}\right)\end{array}$ \\
\hline KOZ1 & 101 & 200 & 127 & 152 \\
\hline KOZ2 & 76 & 175 & 99 & 127 \\
\hline KOZ3 & 74 & 163 & 96 & 124 \\
\hline KOZ4 & 71 & 114 & 93 & 122 \\
\hline KOZ5 & 77 & 173 & 100 & 128 \\
\hline KOZ6 & 79 & 115 & 102 & 130 \\
\hline KOZ1* & 124 & 200 & 151 & 173 \\
\hline KOZ2* & 73 & 158 & 96 & 124 \\
\hline KOZ3* & 68 & 162 & 90 & 119 \\
\hline KOZ4* & 75 & 114 & 98 & 125 \\
\hline KOZ5* & 74 & 168 & 97 & 125 \\
\hline KOZ6* & 76 & 121 & 98 & 126 \\
\hline SP1 & 79 & 166 & 102 & 130 \\
\hline SP2 & 70 & 187 & 92 & 120 \\
\hline SP3 & 80 & 161 & 103 & 130 \\
\hline SP5 & 75 & 168 & 98 & 126 \\
\hline SP6 & 73 & 158 & 96 & 124 \\
\hline SP7 & 75 & 161 & 98 & 126 \\
\hline SP8 & 79 & 158 & 103 & 130 \\
\hline SP9 & 52 & 161 & 73 & 103 \\
\hline SP10 & 52 & 139 & 73 & 103 \\
\hline KOSMS** & 73 & 142 & 95 & 123 \\
\hline Maximum & 124 & 200 & 151 & 173 \\
\hline Minimum & 52 & 114 & 73 & 103 \\
\hline Average & 77 & 157 & 100 & 128 \\
\hline
\end{tabular}

\subsection{Environmental isotopes}

The stable isotope composition of the Kozaklı geothermal fluids is shown in Fig. 5 and Table 3. The $\delta^{2} \mathrm{H}$ values range from -83.31 to $-70.21 \%$, and the $\delta^{18} \mathrm{O}$ values vary between -11.91 and $-10.44 \%$. The stable isotope data indicate that the Kozaklı geothermal fluids are of meteoric origin. Although there are no seasonal differences in the major anion and cation results (Fig. 2), there is a small difference in the $\delta^{18} \mathrm{O}-\delta^{2} \mathrm{H}$ isotope figures. The $\delta^{2} \mathrm{H}$ value for the waters in the rainy season is high due to wells in the study area being fed from surface
Table 3

$\delta^{18} \mathrm{O}-\delta^{2} \mathrm{H}$ isotope results of Kozakl thermal waters.

\begin{tabular}{|c|c|c|c|c|c|}
\hline Sample ID & $\begin{array}{l}\delta{ }^{18} \mathrm{O} \\
\text { (permil) } \\
(\% 0)\end{array}$ & $\begin{array}{l}\delta^{18} \mathrm{O} \\
\text { Standard } \\
\text { Deviation } \\
\text { (permil) (\%o) }\end{array}$ & $\delta^{2} \mathrm{H}(\%)$ & $\begin{array}{l}\delta^{2} \mathrm{H} \\
\text { Standard } \\
\text { Deviation } \\
\text { (permil) (\%) }\end{array}$ & $\begin{array}{l}\text { Deuterium } \\
\text { Excess }\end{array}$ \\
\hline KOZ1 & -10.62 & 0.02 & -83.31 & 0.37 & 1.65 \\
\hline KOZ2 & -10.71 & 0.04 & -81.47 & 0.18 & 4.21 \\
\hline KOZ3 & -10.91 & 0.05 & -79.83 & 0.25 & 7.45 \\
\hline KOZ4 & -11.08 & 0.01 & -72.43 & 0.33 & 16.21 \\
\hline KOZ5 & -10.44 & 0.08 & -80.56 & 0.25 & 2.96 \\
\hline KOZ6 & -10.62 & 0.04 & -70.21 & 0.24 & 14.75 \\
\hline KOZ1* & -10.89 & 0.01 & -76.24 & 0.34 & 10.88 \\
\hline KOZ2* & -11.24 & 0.05 & -74.44 & 0.29 & 15.48 \\
\hline KOZ3* & -11.71 & 0.05 & -77.47 & 0.30 & 16.21 \\
\hline KOZ4* & -11.28 & 0.04 & -72.94 & 0.26 & 17.3 \\
\hline KOZ5* & -11.83 & 0.04 & -78.38 & 0.32 & 16.26 \\
\hline KOZ6* & -11.91 & 0.02 & -70.62 & 0.13 & 24.66 \\
\hline Average & & 0.03 & & 0.27 & \\
\hline
\end{tabular}

waters (Fig. 5). Samples collected in April (*) tend to be more depleted in ${ }^{2} \mathrm{H}$ while December samples show a deuterium excess. Similar ${ }^{2} \mathrm{H}$ depletion in the late spring and early summer (April, May, June) has been noted in other studies in Turkey (Çelmen and Çelik, 2009; Pasvanoğlu et al., 2012; Pasvanoğlu and Chandrasekharam, 2011). In addition, ${ }^{2} \mathrm{H}$ isotopes may be affected by either exsolution of $\mathrm{CH}_{4}$ or $\mathrm{H}_{2} \mathrm{~S}$ (both of which drive residual waters to high ${ }^{2} \mathrm{H}$ ) or water-rock interaction (Fritz and Frape, 1982; Frape and Fritz, 1987).

Isotope values shift from the Mediterranean MWL and Global MWL according to whether they are gathered in arid or rainy periods. Isotope values shift from the meteoric water lines in arid periods and both $\delta^{18} \mathrm{O}$ and $\delta^{2} \mathrm{H}$ isotope values decrease in comparison with those from rainy periods (Fig. 5). This can be explained by evaporation. The annual precipitation in Kozaklı region is $346 \mathrm{~mm}$ and evaporation is $930 \mathrm{~mm}$. A shift from the Mediterranean Meteoric Water Line is related to lowelevation feeding, water-rock interaction or the effect of external contamination. As the elevation increases, more negative values result due to a stable isotope dilution. KOZ1 and $\mathrm{KOZ1*}$ are fed from the highest elevations and KOZ4, KOZ6, KOZ4* and KOZ6* are fed from the lowest elevations, while other locations are fed mainly from medium and high 
Table 4

Rare Earth Element and Yttrium (REY) results (ppm) in water samples collected from the study area.

\begin{tabular}{|c|c|c|c|c|c|c|c|c|c|c|c|c|c|c|c|}
\hline Sample & $\mathrm{La}$ & $\mathrm{Ce}$ & $\operatorname{Pr}$ & $\mathrm{Nd}$ & $\mathrm{Sm}$ & $\mathrm{Eu}$ & $\mathrm{Gd}$ & $\mathrm{Tb}$ & Dy & $\mathrm{Y}$ & Ho & Er & $\mathrm{Tm}$ & $\mathrm{Yb}$ & $\mathrm{Lu}$ \\
\hline KOZ1 & 0.0126 & 0.0237 & 0.0025 & 0.0087 & 0.0015 & 0.0003 & 0.0014 & 0.0002 & 0.0017 & 0.01 & 0.0003 & 0.0011 & 0.0001 & 0.001 & 0.0001 \\
\hline KOZ2 & 0.0374 & 0.0718 & 0.0077 & 0.0265 & 0.0047 & 0.0007 & 0.0042 & 0.0007 & 0.0046 & 0.026 & 0.001 & 0.0029 & 0.0004 & 0.0026 & 0.0003 \\
\hline KOZ3 & 0.0251 & 0.0463 & 0.0049 & 0.0179 & 0.0037 & 0.0009 & 0.0034 & 0.0005 & 0.0036 & 0.0201 & 0.0008 & 0.0023 & 0.0003 & 0.0024 & 0.0003 \\
\hline KOZ4 & 0.0064 & 0.0114 & 0.0011 & 0.004 & 0.0007 & 0.0001 & 0.0007 & 0.0001 & 0.0008 & 0.005 & 0.0002 & 0.0006 & 0.0001 & 0.0006 & 0.0001 \\
\hline KOZ5 & 0.0157 & 0.0293 & 0.0029 & 0.01 & 0.0018 & 0.0004 & 0.0017 & 0.0002 & 0.0018 & 0.0107 & 0.0004 & 0.0012 & 0.0002 & 0.0013 & 0.0001 \\
\hline KOZ6 & 0.0173 & 0.032 & 0.0032 & 0.0112 & 0.0021 & 0.0005 & 0.002 & 0.0003 & 0.0021 & 0.0117 & 0.0004 & 0.0014 & 0.0002 & 0.0014 & 0.0002 \\
\hline KOZ1* & 0.0143 & 0.0302 & 0.0037 & 0.0146 & 0.0032 & 0.0006 & 0.0028 & 0.0004 & 0.0022 & 0.0103 & 0.0004 & 0.001 & 0.0001 & 0.0008 & 0.0001 \\
\hline KOZ2* & 0.0133 & 0.0271 & 0.0034 & 0.0135 & 0.0029 & 0.0006 & 0.0027 & 0.0003 & 0.0019 & 0.0092 & 0.0003 & 0.0008 & 0.0001 & 0.0006 & 0.00008 \\
\hline KOZ3* & 0.0252 & 0.0505 & 0.0057 & 0.0211 & 0.0042 & 0.0007 & 0.0036 & 0.0005 & 0.0028 & 0.0128 & 0.0005 & 0.0013 & 0.0001 & 0.0009 & 0.0001 \\
\hline KOZ4* & 0.0025 & 0.0064 & 0.0008 & 0.0035 & 0.0009 & 0.0002 & 0.0008 & 0.0001 & 0.0005 & 0.0017 & 0.00009 & 0.0002 & 0.00003 & 0.0001 & 0.00002 \\
\hline KOZ5* & 0.0148 & 0.0314 & 0.0037 & 0.0151 & 0.0036 & 0.0008 & 0.0047 & 0.0007 & 0.0042 & 0.0227 & 0.0008 & 0.0022 & 0.0003 & 0.0019 & 0.0002 \\
\hline KOZ6* & 0.0058 & 0.0141 & 0.0021 & 0.0094 & 0.0024 & 0.0005 & 0.0022 & 0.0002 & 0.0015 & 0.0067 & 0.0002 & 0.0006 & 0.00008 & 0.0004 & 0.00007 \\
\hline
\end{tabular}

elevations. These results are also supported by d-excess values calculated with the formula $\delta=\delta^{2} \mathrm{H}-\left(8 \times \delta^{18} \mathrm{O}\right)$. The d-excess values shown are higher than 10 due to atmospheric water vapor having a rapid evaporation effect on precipitation, while "d" values lower than 10 are caused by slow evaporation in the region.

\subsection{REY geochemistry}

The Cl-chondrite-normalized REY patterns of 12 samples from 6 geothermal wells are shown in Fig. 6 and Table 4. The Kozaklı thermal waters show a variable chemical composition because they originate in various types of aquifer rocks with different suites of REY-bearing accessory minerals. Chondrite-normalized REE concentrations in the water range from $10^{-4}$ to $10^{-1}$. In this study, $\mathrm{Y}$ is included in the REE series because $\mathrm{Y}$ is very similar in size and equal in charge to Ho.

The REY concentrations of the meteoric waters and stream waters are below detection limits, indicating that they are not significant sources of REYs for acid-sulfate waters (Lewis et al., 1994). All water samples exhibit a sub-parallel negative Ce, Eu and Y anomalies (Fig. 6). Negative Ce anomalies are quite common in oxygen-rich surface waters. For instance, seawater, oxygen-rich rivers and karst waters are characterized worldwide by negative Ce anomalies. It is well-known that Ce is a valence-variable element which is easily fractionated from other REYs by particle absorption under oxidizing conditions
(Koeppenkastrop and De Carlo, 1992). Therefore, the occurrence of a Ce negative anomaly in Kozaklı thermal fluids might be attributed either to the oxidation of $\mathrm{Ce}^{3+}$ to $\mathrm{Ce}^{4+}$ and the decreased mobility of the oxidized form in an aqueous environment, or by being inherited from dissolved mineral(s) with a negative Ce anomaly such as limestones.

The negative $\mathrm{Eu} / \mathrm{Eu}^{*}$ in the geothermal precipitates may be related to hydrothermal alteration and therefore, the negative $\mathrm{Eu} / \mathrm{Eu}^{*}$ is inherited by geothermal fluids discharging into the Kozaklı bed. Also, the negative Eu anomalies in waters from Kozaklı are either the result of precipitation of $\mathrm{Ca}$ minerals under high temperatures at depth on the development of negative $\mathrm{Eu} / \mathrm{Eu}^{*}$ in the remaining fluids, as stated by Möller (2000) (Fig. 6).

The $\mathrm{Y}$ anomaly is defined by the $\mathrm{Y} / \mathrm{Ho}$ ratio. Under igneous conditions, Y behaves precisely like Ho (Bau and Dulski, 1996). In aqueous systems, Y displays a different behavior, which may be related to small differences in the solubility products of the hydroxides (Diakonov et al., 1998). In migrating fluids, the small dissimilarity of sorption onto mineral surfaces controlled by surface complexation yields Y-Ho fractionation (Möller, 2000). Unlike the anomalous Eu, the Y/Ho ratio is not principally dependent on temperature. $\mathrm{Y}$ is enriched in ground or thermal water. This anomaly is only acquired when the rock is not in transient equilibrium with the migrating water. If the leaching lasts long enough, equilibrium might be reached and $\mathrm{Y}$ as well as Eu anomalies may vanish. $\mathrm{Y}$ and Ho remain tightly coupled in many

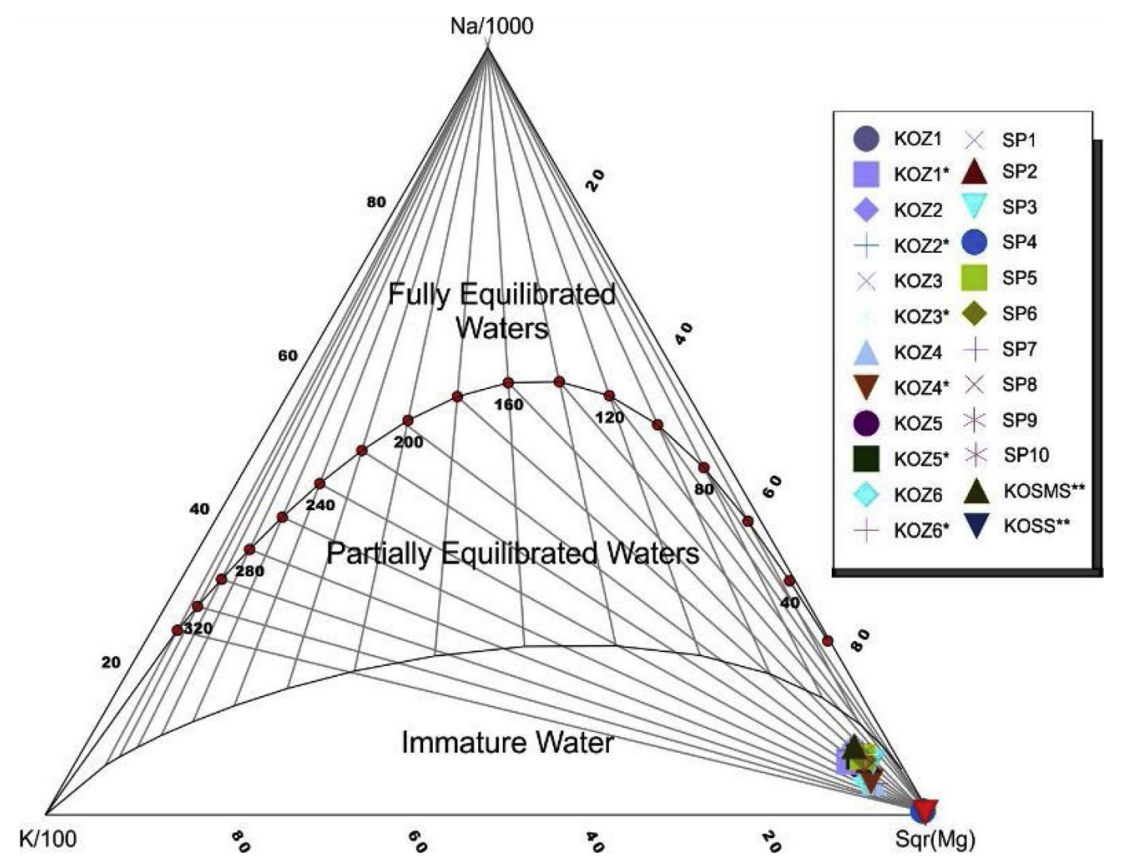

Fig. 4. Diagrammatical evaluation of water-rock equilibration (Giggenbach, 1988) using relative Na, K, and Mg concentrations (mg/L) of Kozaklı waters. 


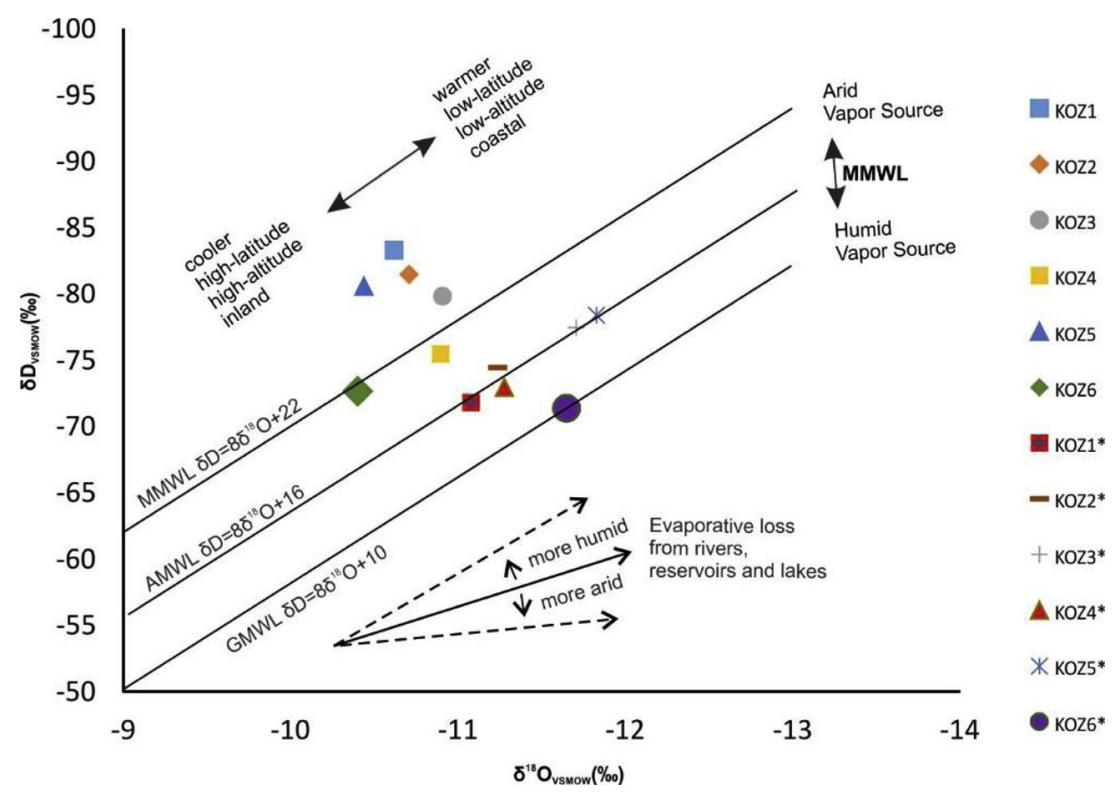

Fig. 5. $\delta^{18} \mathrm{O}-\delta \mathrm{D}$ relations of water samples collected from study area. Vienna Standard Mean Ocean Water (Craig and Gordon, 1965). Shown are the Global Meteoric Water Line (Craig, 1961), Mediterranean Meteoric Water Line (Gat and Carmi, 1987), and Ankara Meteoric Water Line (AMWL; Dirican et al., 2005).

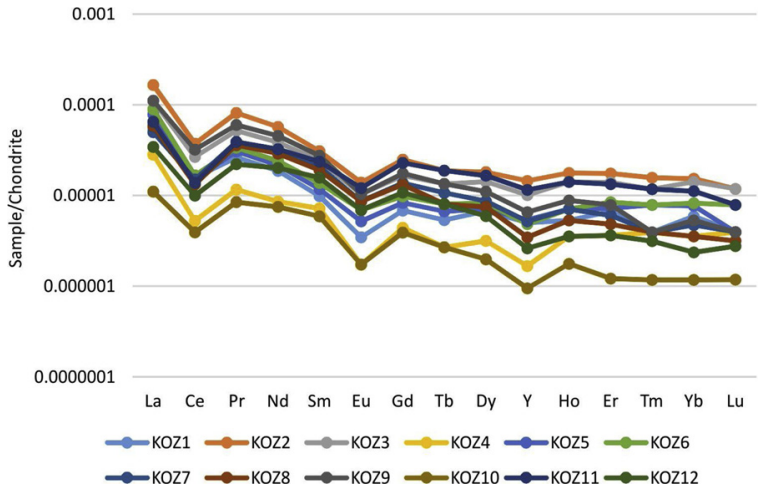

Fig. 6. Chondrite-normalized REE patterns of Kozaklı geothermal field water samples.

geochemical processes, leading to the maintenance of a chondritic $\mathrm{Y} /$ Ho weight-ratio of $22-30$ in common igneous rocks and epiclastic sediments (Bau and Dulski, 1996). The thermal fluids of this study show $\mathrm{Y} /$ Ho values between 23 and 33, which are in agreement with an origin in leached basement rocks and epiclastic sediments (Möller et al., 2004).

\subsection{Conceptual model of the geothermal area}

The conceptual model indicates that the geothermal system is controlled by the KDTZ (Kozakl1-Delice Thrust Zone) to the north and the SFZ (Salanda Fault Zone) and the HFZ (Hırka Fault Zone) to the south. The NW-SE and NE-SW major fault segments intersect other faults in an accommodation zone near the study area (Fig. 7). Normal fault planes cause joints and fractures to remain open around the KDTZ. However, the Miocene and Quaternary cover units include E-W- and NE-SWtrending small-scale faults that do not cut and breach the cover to any great extent. Furthermore, compression components of the strike-slip regime on the NE-SW-trending faults result in compaction, as well as the filling of open fractures with clayey fault breccia, therefore, permeability may be reduced in the cap rock of the system. Enhanced knowledge of the fault segments and strike-slip transfer zones would be very useful to identify geothermal systems such as Kozaklı in the provinces of Nevşehir and Kırşehir.
In the Kozaklı geothermal conceptual model, Paleozoic Kirsehir Massif rocks constitute the basement of the study area. The basement rocks were intruded by Late Cretaceous-Paleocene Baranadag Granitoids, which comprise the heat sources of the geothermal system. Late Eocene-Middle Miocene units overlie the basement units and act as the primary reservoir in the geothermal system. Late Eocene marl and marly limestone units contain small flowing cold water sources. These unite constitute the cap rock of the geothermal system. In addition, the Quaternary travertines and alluvium formed aquifers, in which cold underground waters circulate in the permeable units of the shallow areas while hot fluids circulate in the permeable units of the deep zones. The waters that feed the Kozaklı geothermal system reach the reservoir rock by filtering through crack zones. As the first reservoir rock reached is composed of $\mathrm{CaCO}_{3}$-bearing rocks, after experiencing water-carbonate rock interaction, the waters become $\mathrm{Ca}-\mathrm{HCO}_{3}$ type waters. The deeper-filtered waters react with salts and turn into $\mathrm{Na}-\mathrm{Ca}-\mathrm{Cl}-\mathrm{HCO}_{3}$ type waters; then finally, the deepest-filtered water reacts with anhydrides and turns into $\mathrm{Na}-\mathrm{Ca}-\mathrm{Cl}-\mathrm{SO}_{4}$ type water. Once the meteoric water infiltrates underground, it warms up along the geothermal gradient and flows along fracture and fault zones. During its ascent through the main and secondary faults, the geothermal fluid mixes with cold inlet and younger water. Thus, the meteoric water cannot complete the cycle and undergo water-rock interaction.

\section{Conclusions}

The Kozaklı geothermal field is one of the most important geothermal fields in Central Anatolia. The surface temperature of the fluid ranges from 24.9 to $96^{\circ} \mathrm{C}$. Water samples from Kozaklı shallow well and spring waters are mostly of the $\mathrm{Ca}-\mathrm{Na}-\mathrm{HCO}_{3}$ and $\mathrm{Ca}-\mathrm{Mg}-\mathrm{HCO}_{3}$ types, respectively, whereas the deep geothermal fluids are of the Na-Ca-Cl$\mathrm{SO}_{4}$ type. High correlation in some ionic ratios and high concentrations of some minor elements in the thermal waters studied indicate enhanced water-rock interaction. Kozaklı thermal waters are oversaturated at discharge temperatures with carbonate and silica minerals, allowing an increase in the carbonate- and silica-rich scale, and contributing to travertine precipitation in the discharge area. According to Giggenbach's method, all samples from Kozaklı studied were far from being in full equilibrium, most likely reflecting mixing with cold meteoric water during migration toward springs.

Quartz and chalcedony geothermometers yielded a temperature 


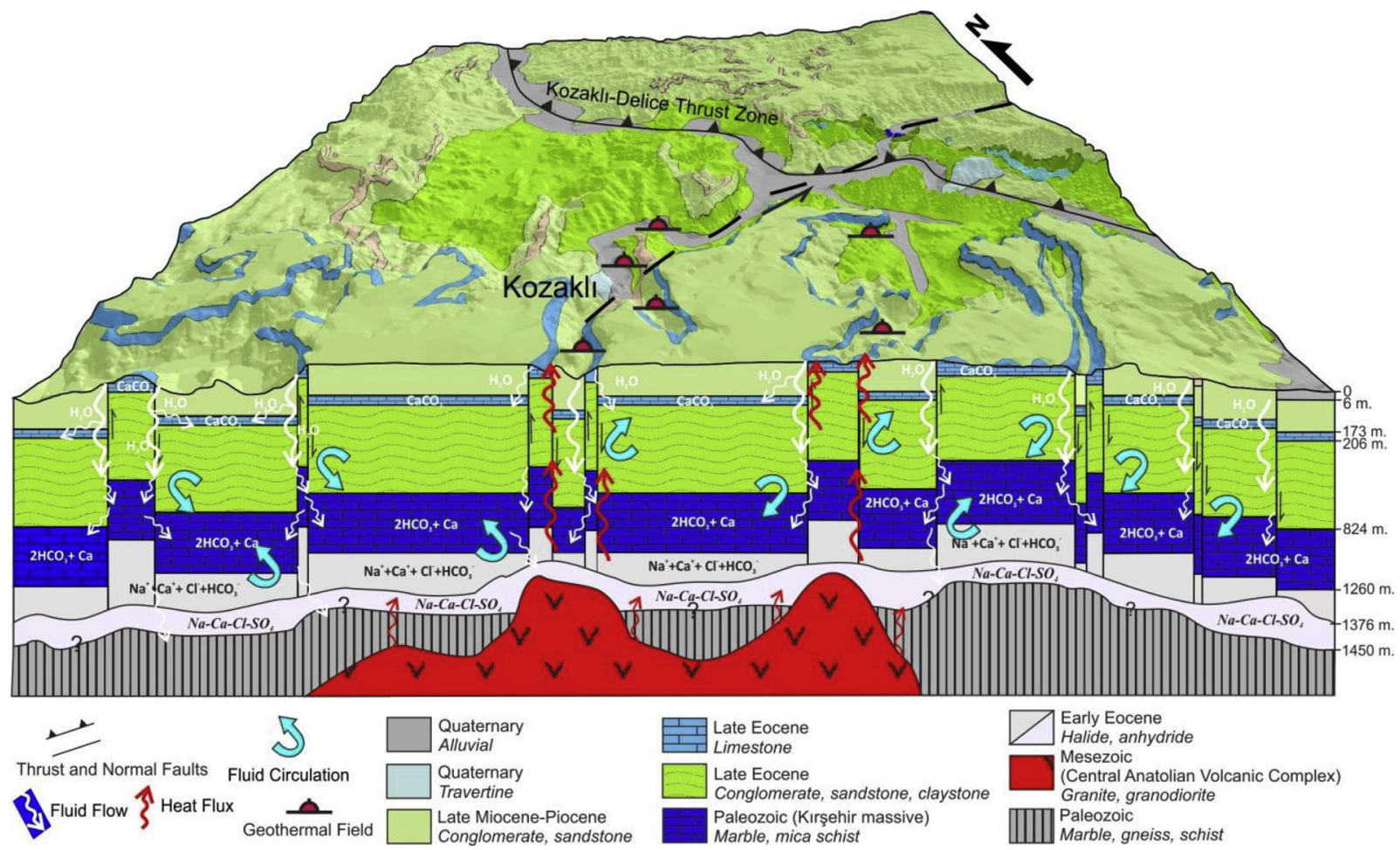

Fig. 7. Conceptual hydrothermal model of the Kozaklı geothermal field (viewed from south).

range from 103 to $173^{\circ} \mathrm{C}$ in the Kozaklı region. The $\delta^{18} \mathrm{O}$ and $\delta^{2} \mathrm{H}$ values for the thermal waters indicate their deep-circulating meteoric origin. These waters likely originate in the infiltration of rainwater through fractures and faults into the deep hot reservoir. Subsequent heating occurs by conduction in the presence of a high geothermal gradient related to the thrust and fault systems. Subsequently, the waters ascend to the surface along faults and fractures that act as hydrothermal pathways.

That the REY signature of the Kozaklı water samples is almost the same and is the result of a combination of processes, such as the oxidizing conditions of water-rock interactions. The variations in $\mathrm{Ce}, \mathrm{Eu}$ and $\mathrm{Y}$ concentrations are the result of inheritance signatures and waterrock interaction. The negative $\mathrm{Ce} / \mathrm{Ce}$ * is the result of the oxidation state of the waters. The negative Eu/ $\mathrm{Eu}^{*}$ anomalies in waters from Kozaklı are either the result of the precipitation of Ca minerals at a high temperature at depth or inherited from mica schists and granites that formed the basement rocks.

The $\mathrm{Y}$ anomaly is defined by the $\mathrm{Y} / \mathrm{Ho}$ ratio. Unlike the anomalous $\mathrm{Eu}$, the $\mathrm{Y} / \mathrm{Ho}$ ratio is not principally dependent on temperature. In all samples, the Y/Ho ratio was around $22-30$, which is common in igneous rocks and epiclastic sediments; this is due to the fact that these waters reach the reservoir rock after leaching from sediment or limestones/marbles.

Understanding the composition of fluids and their sources is mandatory for their usage in geothermal applications. Geochemical properties such as REY minerals (from La to Lu) in geothermal fluids are an important indicator. Geothermal fluids such as in the Kozaklı region are of a variable chemical composition because they originate in diverse reservoir rocks with different suites of REY-bearing accessory minerals. Therefore, geothermal fluids from different types of rocks, such as magmatic rocks, show different types of REY patterns, normally with positive $\mathrm{Y}$ anomalies. In particular, geothermal fluids from magmatic and metamorphic rocks show negative Eu anomalies. Geothermal fluids are potentially significant sources of elements. It is important to know the behavior of major ions and REYs in geothermal fluids. Rare earth elements play a vital role in the evaluation of a geothermal system. The signatures of REYs and the fluid chemistry being almost the same is the result of a combination of processes, such as the oxidizing conditions of water-rock interactions. The The $\mathrm{Ce}, \mathrm{Eu}$ and $\mathrm{Y}$ anomalies result from the leaching of basement rocks and limestone/marble units. Although all geothermal waters from the CAGP belong to the same system, the waters from Nigde, Nevsehir and Kirsehir differ in REY anomalies. In conclusion, the results show that it is possible for a high temperature reservoir to be found in the Kozaklı area. No detailed geophysical surveys have yet been carried out nor deep wells drilled to investigate the subsurface structure of the region. Seismic and Magnetotelluric (MT) research in this area may provide vital clues concerning the reservoir system; however, exploratory drilling is necessary for further development of the area.

\section{References}

Afsin, M., Allen, D.M., 2012. Hydrochemical and Isotopic Characteristics of Geothermal Waters in Central Anatolia, Turkey. Presented at the 39th IAH Congress. Confronting Global Change, Toronto, Canada p. 400.

Akkuş, İ., 2017. Importance of geothermal energy in Turkey. Mavi Gezegen 25-39. Atabey, E., 1989. 1/100.000 ölçekli açınsama nitelikli Türkiye Jeoloji Haritaları Serisi. Kayseri-H 19 paftas1.

Baba, A., 2018. Naturally occurring arsenic in geothermal systems: case study: Turkey. Presented at the As 2018, 7th International Congress \& Exhibition on Arsenic in the Environment.

Baba, A., Ármannsson, H., 2006. Environmental impact of the utilization of geothermal areas. Energy Sources B Econ. Plan. Policy 1, 267-278. https://doi.org/10.1080/ 15567240500397943.

Bau, M., Dulski, P., 1996. Anthropogenic origin of positive gadolinium anomalies in river waters. Earth Planet. Sci. Lett. 143, 245-255. https://doi.org/10.1016/0012-821X (96)00127-6.

Byrne, R.H., Lee, J.H., 1993. Comparative yttrium and rare earth element chemistries in seawater. Mar. Chem. 44, 121-130.

Çelmen, O., Çelik, M., 2009. Hydrochemistry and environmental isotope study of the geothermal water around Beypazarı granitoids, Ankara, Turkey. Environ. Geol. 58, 1689-1701. https://doi.org/10.1007/s00254-008-1669-2.

Craig, H., 1961. Isotopic variations in meteoric waters. Science 133, 1702-1703. https:// doi.org/10.1126/science.133.3465.1702.

Craig, H., Gordon, L.I., 1965. Deuterium and oxygen 18 variations in the Ocean and the marine atmosphere. Consiglio nazionale delle richerche, Laboratorio de geologia nucleare.

Diakonov, I.I., Ragnarsdottir, K.V., Tagirov, B.R., 1998. Standard thermodynamic properties and heat capacity equations of rare earth hydroxides:: II. Ce(III)-, Pr-, Sm-, Eu 
(III)-, Gd-, Tb-, Dy-, Ho-, Er-, Tm-, Yb-, and Y-hydroxides. Comparison of thermochemical and solubility data. Chem. Geol. 151, 327-347. https://doi.org/10.1016/ S0009-2541(98)00088-6.

Dirican, A., Unal, S., Acar, Y., Demircan, M., 2005. The Temporal and Seasonal Variation of H-2 and O-18 in Atmospheric Water Vapour and Precipitation From Ankara, Turkey in Relation to Air Mass Trajectories at Mediterranean Basin. (Final Report of a Coordinated Research Project 2000-2004 No. IAEA-TECDOC-1453), Isotopic Composition of Precipitation in the Mediterranean Basin in Relation to Air Circulation Patterns and Climate. International Atomic Energy Agency, Vienna.

Dirik, K., Göncüoğlu, M.C., 1996. Neotectonic characteristics of Central Anatolia. Int. Geol. Rev. 38, 807-817. https://doi.org/10.1080/00206819709465363.

Eggins, S.M., Woodhead, J.D., Kinsley, L.P.J., Mortimer, G.E., Sylvester, P., McCulloch, M.T., Hergt, J.M., Handler, M.R., 1997. A simple method for the precise determination of $\geq 40$ trace elements in geological samples by ICPMS using enriched isotope internal standardisation. Chem. Geol. 134, 311-326. https://doi.org/10.1016/ S0009-2541(96)00100-3.

Elderfield, H., Upstill-Goddard, R., Sholkovitz, E.R., 1990. The rare earth elements in rivers, estuaries, and coastal seas and their significance to the composition of ocean waters. Geochim. Cosmochim. Acta 54, 971-991.

Erişen, B., Özgür, R., 1999. Jeotermal Enerji Olanaklarına İlişkin Değerlendirme Raporu (No. 10376). Maden Tetkik ve Arama Genel Müdürlüğ̈u, Ankara, Turkey.

Fee, J.A., Gaudette, H.E., Lyons, W.B., Long, D.T., 1992. Rare earth element distribution in the Lake Tyrrell groundwaters, Victoria, Australia. Chem. Geolol. 96, 67-93.

Fournier, R.O., 1977. Chemical geothermometers and mixing models for geothermal systems. Presented at the In: Proceedings of the Symposium on Geothermal Energy, Cento Scientific Programme 199-210.

Fournier, R.O., 1991. Water geothermometers applied to geothermal energy. Center on Small Energy Resources 37-69.

Frape, S.K., Fritz, P., 1987. Geochemical trends for groundwaters from the Canadian shield. Saline Water and Gases in Crystalline Rocks, vol. 33. Geological Association of Canada, Ottawa, pp. 19-38.

Fritz, P., Frape, S.K., 1982. Saline groundwaters in the Canadian Shield-a first overview. Chem. Geol. 179-190.

Gat, J.R., Carmi, I., 1987. Effect of climate changes on the precipitation patterns and isotopic composition of water in a climate transition zone: case of the Eastern Mediterranean Sea area. Presented at the The Influence of Climate Change and Climatic Variability on the Hydrologie Regime and Water Resources. IAHS, pp. 513-523.

Gat, J.R., Matsui, E., 1991. Atmospheric water balance in the Amazon Basin: an isotopic evapo-transpiration model. J. Geophys. Res. 96 (13) 179-13 188.

Giggenbach, W.F., 1988. Geothermal solute equilibria. Derivation of Na-K-Mg-Ca geoindicators. Geochim. Cosmochim. Acta 52, 2749-2765. https://doi.org/10.1016/00167037(88)90143-3.

Goldstein, S.J., Jacobsen, S.B., 1988. Nd and Sr isotopic systematics of river water suspended material: implications for crustal evolution. Earth Planet. Sci. Lett. 87 (3), 249-265.

Göncüoglu, M.C., Toprak, V., Kuşçu, I., Erler, A., Olgun, E., 1991. Orta Anadolu Masifinin Bat1 Bölümünün Jeolojisi, Bölüm 1-Güney Kesim: (No. 2909). Türkiye Petrolleri Anonim Ortaklığı, Ankara, Turkey.

Johannesson, K.H., Stetzenbach, K.J., Hodge, V.F., 1997. Rare earth elements as geochemical tracers of regional groundwater mixing. Geochim. Cosmochim. Acta 61, 3605-3618. https://doi.org/10.1016/S0016-7037(97)00177-4.

Jouzel, J., Merlivat, L., 1984. Deuterium and oxygen-18 in precipitation: modelling of the isotopic effect during snow formation. J. Geophys. Res. 89 (11) 749-11 757.

Koçyiğit, A., 1984. Güneybatı Türkiye ve yakın dolayında levha içi tektonik gelişimi. Ball. Geol. Soc. Turkey 27.

Koçyiğit, A., Doğan, U., 2016. Strike-slip neotectonic regime and related structures in the Cappadocia region: a case study in the Salanda basin, Central Anatolia, Turkey. Turk. J. Earth Sci. 25, 393-417. https://doi.org/10.3906/yer-1512-9.

Koeppenkastrop, D., De Carlo, E.H., 1992. Sorption of rare-earth elements from seawater onto synthetic mineral particles: an experimental approach. Chem. Geolol. 95, 251-263.

Lawrence, M.G., Kamber, B.S., 2006. The behaviour of the rare earth elements during estuarine mixing—revisited. Mar. Chem. 100, 147-161. https://doi.org/10.1016/j. marchem.2005.11.007.

Lewis, A.J., Palmer, M.R., Kemp, A.J., 1994. Variations of the Rare Earth Element Abundances in Hydrothermal Waters From the Yellowstone Hydrothermal System.
Mineralogical Magazine 58A, Wyoming, USA, pp. 525-526.

Möller, P., 2000. Rare earth elements and yttrium as geochemical indicators of the source of mineral and thermal waters, in: hydrogeology of crystalline Rocks. Water Science and Technology Library. Springer, Dordrecht, pp. 227-246.

Möller, P., Dulski, P., Gerstenberger, H., Morteani, G., Fuganti, A., 1998. Rare earth elements, yttrium and $\mathrm{H}, \mathrm{O}, \mathrm{C}, \mathrm{Sr}, \mathrm{Nd}$ and $\mathrm{Pb}$ isotope studies in mineral waters and corresponding rocks from NW-Bohemia, Czech Republic. Appl. Geochem. 13, 975-994. https://doi.org/10.1016/S0883-2927(98)00024-9.

Möller, P., Dulski, P., Savascin, Y., Conrad, M., 2004. Rare earth elements, yttrium and Pb isotope ratios in thermal spring and well waters of West Anatolia, Turkey: a hydrochemical study of their origin. Chem. Geol. 206, 97-118. https://doi.org/10.1016/j. chemgeo.2004.01.009.

Mutlu, H., 1998. Chemical geothermometry and fluid-mineral equilibria for the Ömer-Gecek thermal waters, Afyon area, Turkey. J. Volcanol. Geotherm. Res. 80, 303-321. https://doi.org/10.1016/S0377-0273(97)00051-6.

Ok, G., 2007. Kozaklı (Nevsehir) ve Terme (Kirsehir) Sicak ve Mineralli Sularının Su Kimyasi ve İzotopik Yöntemlerle Karşılaștırılması. Tıbbi ve Biyoiklimsel Değerlendirmesi (MS Thesis). Niğde Üniversitesi, Aksaray.

Özgür, R., Uygur, N., Güdücü, A., Önder, M., 1997. Nevşehir-Kozaklı K-1 sıcak su sondaj1 kuyu bitirme raporu. (No. 10275). Maden Tetkik ve Arama Genel Müdürlüğüu, Ankara, Turkey.

Öztürk, M.Z., Şener, M.F., Şener, M., Şahiner, E., 2018. Tuzgölü Fay Zonu Bor Segmenti’nin Kuvaterner Atım Miktarı. Ömer Halisdemir Üniversitesi Mühendislik Bilimleri Dergisi 7 (3), 1049-1053.

Pasvanoğlu, S., Chandrasekharam, D., 2011. Hydrogeochemical and isotopic study of thermal and mineralized waters from the Nevsehir (Kozakli) area, Central Turkey. J. Volcanol. Geotherm. Res. 202, 241-250. https://doi.org/10.1016/j.jvolgeores.2011. 03.003.

Pasvanoğlu, S., Güner, A., Gültekin, F., 2012. Environmental problems at the Nevşehir (Kozakli) geothermal field, central Turkey. Environ. Earth Sci. 66, 549-560. https:// doi.org/10.1007/s12665-011-1264-9.

Piper, A.M., 1944. A Graphic Procedure in the Geochemical Interpretation of WaterAnalyses. Transactions, vol. 25. American Geophysical Union, pp. 914. https://doi. org/10.1029/TR025i006p00914.

Şener, M.F., 2019. A new approach to Kırşehir (Turkey) geothermal waters using REY, major elements and isotope geochemistry. Environ. Earth Sc1 (in press).

Sener, M.F., Sener, M., Uysal, I.T., 2017. The evolution of the Cappadocia Geothermal Province, Anatolia (Turkey): geochemical and geochronological evidence. Hydrogeol. J. 25, 2323-2345. https://doi.org/10.1007/s10040-017-1613-1.

Şener, M.F., Şener, M., Öztürk, M.Z., 2018. Seyfe Fay Zonuna Ait Kil Minerallerinin Yaş1, Petrografisi ve Kinematiği: Orta Anadolu, Türkiye. Ömer Halisdemir Üniversitesi Mühendislik Bilimleri Dergisi 7 (3), 1066-1071.

Şengör, A.M.C., Canitez, N., 2013. The North Anatolian fault. Alpine-Mediterranean Geodynamics. American Geophysical Union (AGU), pp. 205-216.

Seymen, I., 1981. Kaman (Kırșehir) dolayında Kırșehir masifinin stratigrafisi ve metamorfizması. Presented at the 24. Türkiye Jeoloji Kurultayı, MTA, Ankara, Turkey, pp. 101-108.

Shabani, M.B., Akagi, T., Masuda, A., 1992. Preconcentration of trace rare-earth elements in seawater by complexation with bis(2-ethylhexyl) hydrogen phosphate and 2ethylhexyl dihydrogen phosphate adsorbed on a C18 cartridge and determination by inductively coupled plasma mass spectrometry. Anal. Chem. 64, 737-743. https:// doi.org/10.1021/ac00031a008.

Şimşek, Ş., 2009. New Wide development of geothermal power production in Turkey. Presented at the International Geothermal Days Slovakia. Casta Papiernicka, Slovakia p. 8.

Smedley, P.L., 1991. The geochemistry of rare earth elements in groundwater from the Cammenellis area, southwest England. Geochim. Cosmochim. Acta 55, 2767-2779.

Temiz, U., Gökten, E., Eikenberg, J., 2009. U/Th dating of fissure ridge travertines from the Kirsehir region (Central Anatolia Turkey): structural relations and implications for the Neotectonic development of the Anatolian block. Geodin. Acta 22, 201-213. https://doi.org/10.3166/ga.22.201-213.

Toprak, V., Göncöoḡlu, M.C., 1993. Tectonic control on the development of the neogene-quaternary central anatolian volcanic province, Turkey. Geol. J. 28, 357-369. https://doi.org/10.1002/gj.3350280314.

Zhang, J., Liu, C.-Q., 2004. Major and rare earth elements in rainwaters from Japan and East China Sea: natural and anthropogenic sources. Chem. Geolol. 209 (3-4), $315-326$. 